\title{
Role of adiponectin and leptin on body development in infants during the first year of life
}

Elena Bozzola', Cristina Meazza ${ }^{1}$, Marica Arvigo ${ }^{2}$, Paola Travaglino ${ }^{1}$, Sara Pagani ${ }^{1}$, Mauro Stronati ${ }^{3}$, Antonella Gasparoni ${ }^{4}$, Carolina Bianco ${ }^{1}$, Mauro Bozzola ${ }^{1 *}$

\begin{abstract}
Background: The control of growth and nutritional status in the foetus and neonate is a complex mechanism, in which also hormones produced by adipose tissue, such as adiponectin and leptin are involved. The aim of this study was to evaluate levels of adiponectin, leptin and insulin in appropriate (AGA) and small for gestational age (SGA) children during the $1^{\text {st }}$ year of life and to correlate these with auxological parameters.

Methods: In 33 AGA and 29 SGA infants, weight, length, head circumference, glucose, insulin, adiponectin and leptin levels were evaluated at the second day of life, and at one, six and twelve months, during which a portion of SGA could show catch-up growth (rapid growth in infants born small for their gestational age).

Results: Both total and isoform adiponectin levels were comparable between AGA and SGA infants at birth and until age one year. These levels significantly increased from birth to the first month of life and then decreased to lower values at 1 year of age in all subjects. Circulating leptin concentrations were higher in AGA $(2.1 \pm 4.1 \mathrm{ng} / \mathrm{ml})$ than in SGA neonates $(0.88 \pm 1.03 \mathrm{ng} / \mathrm{ml}, \mathrm{p}<0.05)$ at birth, then similar at the $1^{\text {st }}$ and the $6^{\text {th }}$ month of age, but they increased in SGA from six months to one year, when they showed catch-up growth. Circulating insulin levels were not statistically different in AGA and SGA neonates at any study time point. Insulin levels in both AGA and SGA infants increased over the study period, and were significantly lower at birth compared to one, six and 12 months of age.
\end{abstract}

Conclusions: During the first year of life, in both AGA and SGA infants a progressive decrease in adiponectin levels was observed, while a difference in leptin values was correlated with the nutritional status.

\section{Background}

Epidemiological studies have shown an association between a reduced size at birth and increased long-term risk for obesity, insulin resistance, type 2 diabetes, hypertension and cardiovascular disease in adulthood [1-3]. Low birth weight has been associated with hyperinsulinaemia in both children [4,5] and adults [6], suggesting that this metabolic abnormality may be the link between reduced prenatal growth and certain endocrinological diseases in adulthood. In particular, the transition from a relatively low birth weight to larger post-natal body size is associated with an increased risk for insulin resistance

\footnotetext{
* Correspondence: mauro.bozzola@unipv.it

${ }^{1}$ Paediatrics Department, University of Pavia, Fondazione IRCCS Policlinico San Matteo, Piazzale Golgi 2, Pavia, Italy
}

[7-9]. It, therefore, seems that small birth size, and particularly low birth weight are factors that greatly increase the risk of developing endocrine and metabolic diseases in adulthood [9].

A role for adipose tissue in the pathophysiology of insulin resistance has been postulated in several studies [10]. It is currently known to secrete a large number of factors with diverse functions, such as free fatty acids, with well described physiological and pathophysiological effects on glucose homeostasis [11], and proteins, termed adipocytokines, that act in an autocrine, paracrine, or endocrine fashion to control various metabolic functions. Some of these adipocytokines, such as adiponectin, leptin, tumour necrosis factor- $\alpha$ (TNF- $\alpha$ ) and interleukin-6 (IL-6), may act locally or distally to alter 
insulin sensitivity in insulin-targeted organs such as muscle and the liver or may act through neuroendocrine, autonomic or immune pathways [12]. Adiponectin and leptin are considered the most important hormones related to adipose depots in modulating metabolism and energy homeostasis [12].

In adult humans, plasma adiponectin is an important insulin sensitizer, as its circulating level is inversely related to the body mass index and to measures of insulin resistance [13]. Since foetal growth is to a great extent controlled by the actions of insulin, adiponectin could also be expected to have significant effects on foetal growth and development. In the circulation, adiponectin exists as low-, medium- and high molecular weight complexes that appear to elicit different effects on target tissues [14]. In particular, the high molecular weight isoform has been linked with insulin-sensitizing activity [15].

Circulating leptin concentrations, mainly produced by white adipose tissue, correlate with the development of foetal adipose tissue and later with the body mass index [16]. The role of leptin among the complex network of factors controlling foetal growth is incompletely understood, even though recent studies have demonstrated a strong correlation between leptin in cord blood and foetal birth weight $[17,18]$.

The aim of the present study was to evaluate serum levels of leptin, adiponectin and insulin in infants born appropriate for gestational age (AGA) and small for gestational age (SGA) during the first year of life and to correlate these changes with auxological parameters.

\section{Methods}

Thirty-three AGA (birth weight $>-2$ SD according to gestational age and gender) [19] infants (21 males and 12 females) and 29 SGA (birth weight $<-2$ SD according to gestational age and gender) infants (19 males and 10 females), participated in the study. According to gestational age at delivery, all the neonates were fullterm ( $38 \pm 1$ weeks of gestation). Gestational age at delivery was calculated according to the last menstrual period and confirmed by ultrasound examination during the first trimester or early second trimester. The mothers of the neonates enrolled confirmed the normal course of the pregnancy, without any complications or administration of drugs. Thirty-five neonates (17 SGA and 18 AGA) were born by eutocic birth, while 27 (12 SGA and 15 AGA) were delivered by caesarean section.

Neonates were randomly recruited at birth from the Neonatal Units of the Spedali Civili Hospital of Brescia and the San Matteo Hospital of Pavia, Italy.

Subjects with evidence of malformations or genetic disorders were excluded from the study. Mid-parental height, used as an indicator of the genetic growth potential, was similar in AGA (mean \pm standard deviation: $0.31 \pm 0.82$ SDS, standard deviation score) and SGA groups $(-0.12 \pm 0.85$ SDS $)$.

Among SGA infants, 16 were symmetrical and 13 asymmetrical. We defined "symmetrical SGA" neonates as having both birth length and weight less than 2 SDS corrected for gestational age and "asymmetrical SGA" neonates with birth weight only less than -2 SDS corrected for gestational age.

The infants had similar diets, during the first year of life, they received only milk until the fourth month, then one solid meal was introduced at the sixth month and two solid meals at the eighth month.

In all infants, weight, length and head circumference were evaluated at the second day of life, and at one, six and 12 months by a trained paediatrician, and converted to SDS to adjust for age and sex $[20,21]$. The body mass index (BMI) was used as a measurement of relative adiposity and was calculated according to the formula: weight $(\mathrm{Kg}) /$ length ${ }^{2}\left(\mathrm{~m}^{2}\right)$ [21].

At regularly scheduled control visit, a blood sample was obtained from each neonate (in the fasting state) for the determination of glucose, insulin, adiponectin and leptin. In order to avoid possible confounders in assessing hormone levels at birth, we took blood samples from the neonates on the $2^{\text {nd }}$ day of life and did not use cord blood in which hormone levels may derive from the maternal circulation or from other maternal tissues, such as the placenta [22,23].

The study protocol was approved by the local Ethics Committee. The study's purpose was fully explained to each pregnant woman and written informed consent was obtained before enrolment.

Glucose was measured immediately using a commercial glucometer (One touch Ultra, Lifescan, Johnson Johnson company). Blood samples were then centrifuged and serum was frozen at $-20^{\circ} \mathrm{C}$ until the measurements were performed.

Serum adiponectin and leptin concentrations were measured by a commercially available ELISA assay (BBridge International, Inc, Sunnyvale CA, USA and R\&D Systems, Minneapolis MN, USA, respectively). The minimum detectable concentration for adiponectin was $375 \mathrm{pg} / \mathrm{ml}$ and the intra- and inter-assay coefficient of variation ranges were $3.2-7.3 \%$ and $4.6-5.8 \%$ for a quality control range of $0.7-2.9 \mathrm{ng} / \mathrm{ml}$, respectively. The minimum detectable concentration for leptin was $15.6 \mathrm{pg} / \mathrm{ml}$ and the intra- and inter-assay coefficient of variation ranges were $3.2-3.3 \%$ and $3.5-5.4 \%$ for a quality control range of $65-600 \mathrm{ng} / \mathrm{ml}$, respectively.

Serum insulin levels were measured by an automatic chemiluminescent assay ADVIA centaur IRI (Bayer Diagnostics Europe, Dublin, Ireland). The minimum concentration detectable by this assay is $0.1 \mu \mathrm{U} / \mathrm{ml}$. The 
intra- and inter-assay coefficients of variation were 2.1$5.0 \%$ and $4.2-6.3 \%$ for a quality control range of $0.6-4.0$ $\mu \mathrm{U} / \mathrm{ml}$, respectively.

Insulin resistance was estimated with fasting insulin and glucose levels using the homeostasis model assessment insulin resistance index (HOMA-IR), using the following formula: fasting serum insulin $(\mu \mathrm{U} / \mathrm{ml}) \times$ fasting plasma glucose $(\mathrm{mmol} / \mathrm{L}) / 22.5$.

Although the HOMA-IR measure is less accurate than the euglycemic clamp method used in large epidemiological studies, it is a reasonable alternative to the complicated clamp method that requires continuous intravenous administration of insulin and glucose for $3 \mathrm{~h}$ to calculate insulin sensitivity [24]. A HOMA-IR value $>3$ was chosen as an indicator of reduced insulin sensitivity [25].

Even if the gold standard techniques for measuring insulin sensitivity in children are Bergman's minimal model and the hyperinsulinaemic-euglycemic clamp $[26,27]$, the evaluation of insulin sensitivity starting from basal insulin levels has been validated in non-diabetic children as well as in children of one year of age [28-30] and the use of HOMA-IR has been reported in previous paediatric studies [31,32].

Samples of $250 \mu \mathrm{l}$ of pooled serum were gel-filtered on HyPrep 16/60 Sephacryl-S-200 High Resolution columns equilibrated with $0.05 \mathrm{M} \mathrm{NaH}_{2} \mathrm{PO}_{4} / 0.15 \mathrm{M} \mathrm{NaCl} /$ $0.02 \% \mathrm{NaN}_{3}$ elution buffer. One minute fractions, eluted with $0.8 \mathrm{ml} / \mathrm{min}$ flow rate, were analysed for adiponectin content with the ELISA assay.

Data were analysed using the statistical analysis software package Statistica 7.0 (Stasoft Inc). Descriptive statistics were calculated and reported as the mean and standard deviation. Non parametric tests were used for statistical analysis. The Mann-Whitney U test for unpaired samples was used to compare anthropometrical and laboratory parameters between SGA and AGA infants, at each time point of the study. The non-parametric Wilcoxon test for paired samples was used to compare anthropometrical and laboratory parameters at different times. Correlations were analysed using the Spearman rank correlation test. A p value $<0.05$ was considered statistically significant.

\section{Results}

\section{Auxology}

As shown in table 1, symmetrical SGA infants weighted less and were shorter at birth, at one and 12 months of life compared to AGA infants. On the contrary, asymmetrical SGA infants showed a lower BMI only at birth and at one month compared to AGA infants. Furthermore, head circumferences were smaller in both symmetrical and asymmetrical SGA infants from birth to six months of age but they became comparable to those of AGA infants at one year. Symmetrical SGA infants were, by definition, significantly shorter $(p<0.05)$ than asymmetrical SGA infants at birth and also at 1, 6 and 12 months of age.

\section{Circulating levels of adiponectin}

As shown in figure 1A, both AGA and SGA fasting adiponectin levels showed statistically significant changes over time ( $\mathrm{p}<0.0005$ by Wilcoxon test). In particular,

Table 1 Anthropometrical measurements of AGA, symmetrical and asymmetrical SGA at birth, 1, 6 and 12 months of life.

\begin{tabular}{|c|c|c|c|c|}
\hline AGA & Birth & 1 month & 6 months & 12 months \\
\hline Length (SDS) & $0.31 \pm 0.78 \#$ & $0.39 \pm 0.87 \#$ & $-0.15 \pm 0.90$ & $-0.40 \pm 0.95$ \\
\hline Weight (SDS) & $-0.23 \pm 0.66 \#$ & $-0.24 \pm 1.22$ & $0.26 \pm 0.98$ & $0.19 \pm 1.05$ \\
\hline BMI (SDS) & $-0.06 \pm 0.84 \S$ & $0.70 \pm 0.86$ & $0.77 \pm 1.14$ & $0.38 \pm 1.03$ \\
\hline Head circumference (SDS) & $0.49 \pm 0.76 \#$ & $0.28 \pm 1.05 \#$ & $0.61 \pm 1.14 \#$ & $-0.70 \pm 0.69$ \\
\hline \multicolumn{5}{|l|}{ Symmetrical SGA } \\
\hline Length (SDS) & $-1.82 \pm 0.85^{*}$ & $-1.21 \pm 1.29^{*}$ & $-1.47 \pm 0.81^{*}$ & $-1.85 \pm 0.54^{*}$ \\
\hline Weight (SDS) & $-2.45 \pm 0.75^{*}$ & $-2.52 \pm 1.97^{*} \#$ & $-1.43 \pm 1.54^{*} \#$ & $-1.93 \pm 1.62^{*}$ \\
\hline BMI (SDS) & $-1.53 \pm 0.60^{*} \S$ & $-0.61 \pm 1.19^{*}$ & $0.33 \pm 1.19$ & $-0.27 \pm 1.02^{*}$ \\
\hline Head circumference (SDS) & $-1.01 \pm 0.88^{*}$ & $-0.75 \pm 1.01^{*}$ & $-0.47 \pm 0.76^{*}$ & $-1.25 \pm 0.77$ \\
\hline \multicolumn{5}{|l|}{ Asymmetrical SGA } \\
\hline Length (SDS) & $-0.29 \pm 0.62 \wedge$ & $-0.10 \pm 0.69 \wedge \#$ & $-0.47 \pm 0.57 \wedge$ & $-0.70 \pm 0.61 \wedge$ \\
\hline Weight (SDS) & $-1.84 \pm 0.27^{*} \# \S$ & $-1.25 \pm 0.84^{*}$ & $-0.19 \pm 1.38$ & $-0.73 \pm 1.40$ \\
\hline BMI (SDS) & $-1.80 \pm 0.49^{*} \# \S$ & $-0.54 \pm 1.09^{*}$ & $0.62 \pm 1.71 \#$ & $0.22 \pm 1.54$ \\
\hline Head circumference (SDS) & $-0.86 \pm 0.91^{*}$ & $-0.65 \pm 1.24^{*}$ & $-0.65 \pm 1.35^{*}$ & $-1.31 \pm 1.24$ \\
\hline
\end{tabular}

* $\mathrm{p}<0.05$ versus AGA at corresponding time (Mann-Whitney $U$ test)

$\wedge p<0.05$ versus symmetrical SGA at corresponding time (Mann-Whitney $U$ test)

$\# \mathrm{p}<0.01$ versus 12 months with respect to the same group (Wilcoxon test)

$\S p<0.001$ versus 1 month with respect to the same group (Wilcoxon test)

Data are shown as mean \pm standard deviation. 

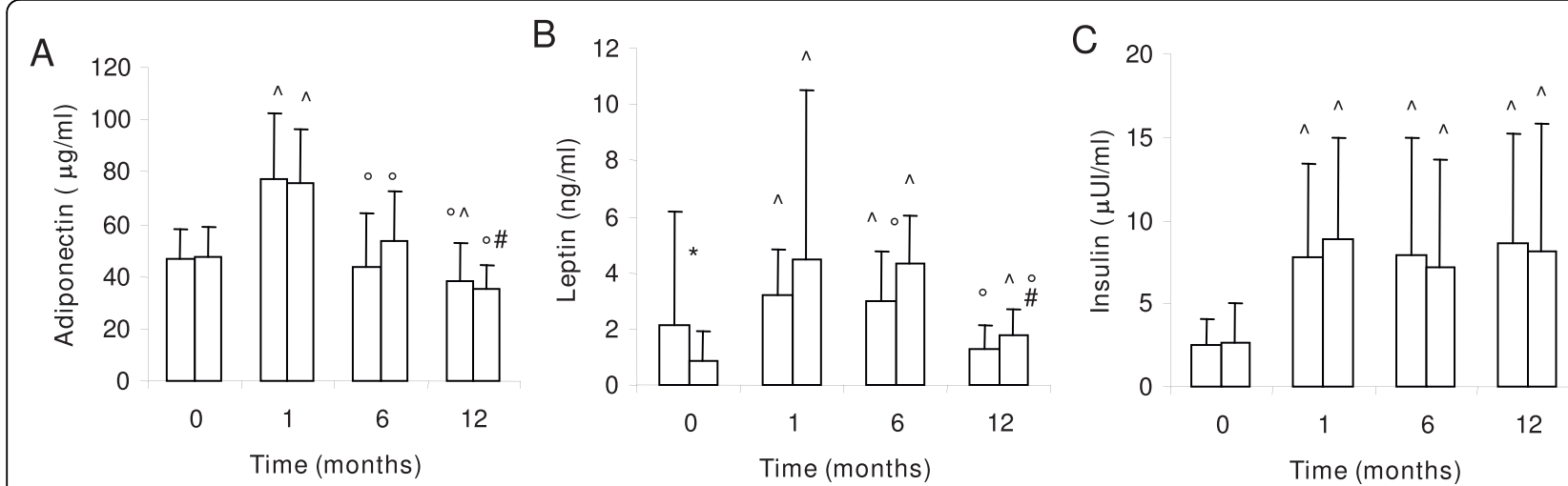

Figure 1 Circulating levels of adiponectin, leptin and insulin. Circulating levels of adiponectin (A), leptin (B) and insulin (C) in AGA (white bars) and SGA (shaded bars) infants at birth and after 1, 6 and 12 months of age. Data are represented as mean+standard deviation. ${ }^{*} p<0.05$ AGA versus SGA (Mann-Whitney $U$ test). $\wedge p<0.05$ AGA or SGA with respect to values at birth (Wilcoxon test). ${ }^{\circ} p<0.05$ AGA or SGA with respect to values at 1 month (Wilcoxon test). \# $p<0.05$ SGA with respect to values at 6 months (Wilcoxon test).

they significantly increased from birth to the first month of life and then decreased to lower values at one year of age in all subjects. Adiponectin levels in AGA and SGA subjects were comparable at all study time points.

In order to investigate whether SGA and AGA subjects show a different distribution of the isomers for adiponectin, we fractioned adiponectin pooled serum samples into the three major molecular fractions, using a validated fast protein liquid chromatography assay. As shown in figure 2, no differences in the fractional adiponectin levels relative to total adiponectin were found between AGA and SGA groups at different time points.

No statistically significant correlations were found between adiponectin levels and auxological parameters at any time point, in any neonate.

No statistically significant difference in adiponectin levels was shown between symmetrical and asymmetrical SGA infants at birth and during the first year of life (table 2). A significant increase in adiponectin values was observed at the first month of age in both groups of subjects and then a statistically significant decrease up to one year of life. Only at six months of age did asymmetric subjects show higher levels of adiponectin than AGA subjects.

\section{Circulating levels of leptin}

As shown in figure $1 B$, leptin levels significantly changed over time both in AGA and SGA infants ( $p<0.005$ by Wilcoxon test). In fact, leptin levels significantly increased from birth to the sixth month in all the neonates and at one year there was a trend to return to birth levels; although at this time, in SGA subjects, leptin levels were significantly higher than at birth. Circulating leptin concentrations at birth were significantly higher in AGA neonates than in SGA infants. At the first, $6^{\text {th }}$ and $12^{\text {th }}$ month of age, leptin returned to a comparable level between the two groups, even if at the latter time point SGA levels were slightly higher than AGA values, the difference was not significant.

A comparison of leptin levels for asymmetrical and symmetrical SGA infants, did not reveal any statistically significant difference at any time during the study (table 2 ). In both groups, the levels were low at birth and significantly increased until six months.

Leptin concentrations at birth were positively correlated with the BMI $(r=0.363, p<0.05)$, birth head circumference $(r=0.434, p<0.05)$ and insulin levels $(r=$ $0.448, \mathrm{p}<0.05)$ in all the infants. After birth, a positive correlation between leptin levels and BMI at six months was found $(R=0.406 ; p<0.05)$ in all neonates and also for AGA and SGA subjects separately.

\section{Circulating levels of insulin}

As shown in figure 1C, insulin levels in both AGA and SGA infants increased over the study period ( $\mathrm{p}<0.05$ by Wilcoxon test); they were significantly lower $(\mathrm{p}<0.05)$ at birth compared to the time points one, six and 12 months of age. SGA circulating insulin levels at birth were lower than AGA levels, although the difference was not statistically significant. At 1, 6 and 12 months, insulin concentrations were comparable between the two groups.

Insulin concentrations for symmetrical and asymmetrical SGA infants were not statistically different at any study time point (table 2), although in asymmetrical subjects they tended to be lower than in symmetrical infants after the first month of age. In both groups, insulin levels were low at birth and tended to increase after the first month of life.

Insulin concentrations at one year of age positively correlated with the BMI $(\mathrm{r}=0.408, \mathrm{p}<0.05)$ and head circumference $(\mathrm{r}=0.436, \mathrm{p}<0.05)$ in all the infants. No other correlations were found at the other time points. 

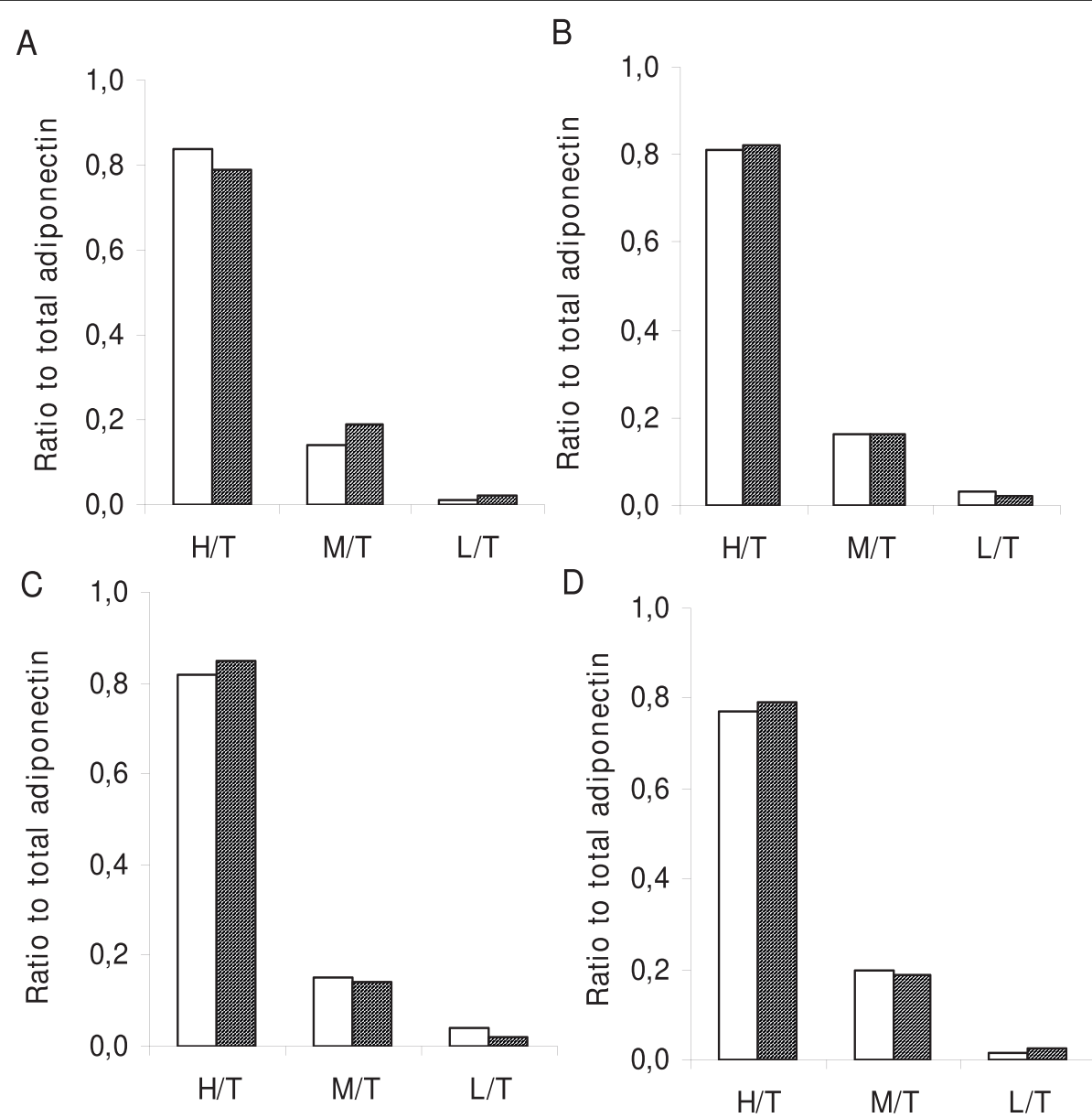

Figure 2 Fractional ratios to total adiponectin. Fractional ratios to total adiponectin in AGA (white bars) and SGA (shaded bars) infants at birth (panel A), after 1 (panel B), 6 (panel C) and 12 months (panel D) of age. $T=$ total adiponectin. $H=$ high molecular weight. $M=$ medium molecular weight. $\mathrm{L}=$ low molecular weight.

In order to evaluate insulin resistance in AGA and SGA subjects during the first year of life, we calculated the HOMA-IR index. Like insulin levels, the HOMA-IR index was comparable between AGA and SGA infants at birth and at all study time points (data not shown). The HOMA-IR index was lower at birth in both groups $(\mathrm{p}<0.01)$ and then increased from the first month to 12 months of age, remaining in the normal range [25].

The HOMA-IR index was also comparable between asymmetric and symmetric SGA infants at all time points.

To further verify the relationship between changes in height SDS and BMI SDS with those of adiponectin, leptin and insulin, we calculated the delta between birth and the first year of life for each parameter and the relationship between each parameter pair (data not shown). We did not observe any significant correlations.

\section{Discussion}

This study presents longitudinal data, from birth to one year of age, on anthropometrical development and serum adiponectin, leptin and insulin levels in a cohort of AGA and SGA infants, including both symmetrical and asymmetrical neonates.

To the best of our knowledge, adiponectin and leptin studies at birth have always been performed on cord blood, which is not considered the ideal material for evaluating these growth stimulating-factors. As we previously indicated, cord blood may present confounding factors [22-25,33]. Our study is the first to report actual circulating levels at birth.

The relationship between adiponectin and foetal growth has been poorly investigated. Some authors have found a positive association between cord blood adiponectin levels and birth-weight [33,34], while others have not [35]. In our study, no significant difference in adiponectin levels was shown between AGA and SGA infants at birth, although SGA neonates weighed significantly less than AGA infants. This result is in accordance with the literature, particularly with the Kamoda et al. study [36]. 
Table 2 Circulating levels of adiponectin, leptin and insulin in AGA, symmetrical and asymmetrical SGA at birth, 1, 6 and 12 months of life.

\begin{tabular}{|c|c|c|c|c|}
\hline$\overline{\mathrm{AGA}}$ & Birth & $\begin{array}{c}1 \\
\text { month }\end{array}$ & $\begin{array}{c}6 \\
\text { months }\end{array}$ & 12 months \\
\hline $\begin{array}{l}\text { Adiponectin } \\
(\mu \mathrm{g} / \mathrm{ml})\end{array}$ & $46.7 \pm 11.5 \#^{*}$ & $77.32 \pm 24.95 \#$ & $43.31 \pm 20.94$ & $38.56 \pm 13.86$ \\
\hline Leptin (ng/ml) & $2.12 \pm 4.08^{*}$ & $3.18 \pm 1.64 \#$ & $2.97 \pm 1.76$ & $1.31 \pm 0.83$ \\
\hline Insulin $(\mu \mathrm{UI} / \mathrm{ml})$ & $2.53 \pm 1.58^{*} \#$ & $7.75 \pm 5.61$ & $7.94 \pm 7.06$ & $8.66 \pm 6.52$ \\
\hline \multicolumn{5}{|l|}{$\overline{S G A}$} \\
\hline $\begin{array}{l}\text { Adiponectin } \\
(\mu \mathrm{g} / \mathrm{ml})\end{array}$ & $47.74 \pm 11.38$ & $75.71 \pm 20.75$ & $53.75 \pm 18.71$ & $35.51 \pm 8.76$ \\
\hline Leptin (ng/ml) & $0.88 \pm 1.04 \S$ & $4.49 \pm 5.99$ & $4.36 \pm 1.69 \S$ & $1.74 \pm 0.96$ \\
\hline Insulin $(\mu \mathrm{UI} / \mathrm{ml})$ & $8.92 \pm 6.05$ & $8.92 \pm 6.05$ & $7.17 \pm 6.44$ & $8.13 \pm 7.67$ \\
\hline \multicolumn{5}{|l|}{ Symmetrical SGA } \\
\hline $\begin{array}{l}\text { Adiponectin } \\
(\mu \mathrm{g} / \mathrm{ml})\end{array}$ & $49.03 \pm 9.93^{*}$ & $79.78 \pm 25.29 \#$ & $44.42 \pm 15.75$ & $33.68 \pm 9.17$ \\
\hline Leptin (ng/ml) & $0.62 \pm 0.37^{*}$ & $6.58 \pm 8.06$ & $4.67 \pm 1.34$ & $2.17 \pm 1.29$ \\
\hline Insulin $(\mu \mathrm{UI} / \mathrm{ml})$ & $2.07 \pm 1.97^{*}$ & $8.96 \pm 5.55$ & $6.83 \pm 3.22$ & $10.0 \pm 8.8$ \\
\hline \multicolumn{5}{|c|}{ Asymmetrical SGA } \\
\hline $\begin{array}{l}\text { Adiponectin } \\
(\mu \mathrm{g} / \mathrm{ml})\end{array}$ & $46.73 \pm 12.89^{*}$ & $71.64 \pm 15.42 \#$ & $64.65 \pm 16.68 \S$ & $36.82 \pm 8.93$ \\
\hline Leptin (ng/ml) & $1.1 \pm 1.4$ & $2.4 \pm 1.6$ & $4.0 \pm 2.1 \#$ & $1.4 \pm 0.56$ \\
\hline Insulin $(\mu \mathrm{UI} / \mathrm{ml})$ & $3.17 \pm 2.67^{*}$ & $8.89 \pm 6.77$ & $7.51 \pm 8.91$ & $5.43 \pm 3.37$ \\
\hline
\end{tabular}

$\S p<0.05$ versus AGA at corresponding time (Mann-Whitney $U$ test)

$\# p<0.01$ versus 12 months of the same group (Wilcoxon test)

${ }^{*} p<0.001$ versus 1 month of the same group (Wilcoxon test)

Furthermore, adiponectin levels do not correlate with birth weight and the physiological relationship with adiposity, observed in adults, is absent at birth.

We found that adiponectin levels in both AGA and SGA neonates were higher than those found in healthy adults in other studies [35]. This is probably due to a lack of negative feedback on adiponectin production resulting from a lack of adipocyte hypertrophy, a low percentage of body fat or a different distribution of fat depots in newborns [37]. The analysis of adipose tissue histology in newborns demonstrated the presence of small cells, that do not contain fat, and larger cells, that contain fat but are small in diameter compared with adult fat cells [37]. These cells are responsible for the increased adiponectin synthesis in neonates. The fall in adiponectin levels at one year of life may be a consequence of the increase in adiposity; as in older children, where adiponectin levels negatively correlate with the percentage of body fat. It has also been reported that low plasma adiponectin concentrations are closely related to hyperinsulinaemia in children $[38,39]$. The lower levels of adiponectin in children at 12 months of age could therefore also be related to the increased concentration of insulin at this time. At one year of age, no statistically significant difference is present in adiponectin levels between AGA and SGA infants, indicating that the long-term risk of diabetes, which has been reported to be associated with low adiponectin levels in prepubertal children [40], is the same in the two groups at this time. In fact, a recent study suggests that the negative correlation between high molecular weight (HMW) adiponectinaemia and fasting insulin levels emerges between two and six years of age and only during this period could a condition of insulin resistance be evidenced [41].

We have also evaluated adiponectin fractions with different molecular weights in SGA and AGA neonates, in order to verify if there was a peculiar distribution of adiponectin isomers. We found a similar chromatographic pattern of adiponectin fractions in AGA and SGA subjects, during the first year of life, confirming the absence of modifications in total circulating adiponectin. Furthermore, in other recent studies by Ibanez et al. $[41,42]$, the authors show comparable levels of HMW adiponectin in AGA and SGA children at age two; the HMW adiponectin concentrations decrease and become significantly lower in SGA children only at age four.

Interestingly, in this study we found leptin levels to be higher in AGA neonates with respect to SGA infants at birth, in accordance with recent studies [43]. On the contrary, at one year of age SGA infants had leptin levels higher than AGA subjects, although the difference was not statistically significant. Small for gestational age infants show an increase in adipose tissue that is a typical phenomenon after a period of undernutrition. Therefore, we 
can speculate that the increased levels of leptin may derive from this increased adipose tissue and may be involved in the early development of insulin resistance [28].

Leptin levels of all the neonates at birth were positively correlated with the BMI and head circumference. This may reflect either a simple relationship with adipose tissue or an active role for leptin in foetal growth, since it is known that leptin plays a role in the development of both the foetus and neonate, influencing also head circumference.

In our report we demonstrated comparable insulin levels and HOMA-IR indices between AGA and SGA infants at birth and at 1, 6 and 12 months of age. Only at birth, were levels of insulin in SGA neonates lower than in AGA infants, but the difference was not statistically significant, probably due to the relatively low number of subjects enrolled in the study. However, insulin levels and HOMA-IR index still remained in the normal range in SGA subjects during the first year of age, suggesting that no insulin resistance develops during this period and that insulin alone does not explain changes in adiponectin levels.

The discrepancies between our results and those showing different insulin levels at birth between AGA and SGA infants and a relationship between birth weight with insulin resistance [43-47] could reflect methodological differences in the assessment of insulin sensitivity and insulin resistance.

\section{Conclusions}

In conclusion, minor changes in serum adiponectin, leptin and insulin levels can be observed in AGA and SGA infants during the first year of life. In particular, a progressive decrease in adiponectin levels is observed, while leptin values change according to nutritional status. In fact, leptin levels in all neonates either at birth or at 6 months positively correlated with the BMI $(\mathrm{p}<0.05)$, confirming that leptin is involved in the regulation of body weight and that its plasma level reflects fat reserves.

\section{Acknowledgements \\ We thank Mrs. Anna Grasso, nurse at the Neonatal Unit, for collecting blood samples and Mrs. Antonella Papalia and Mrs. Donata Frè for excellent technical assistance. The authors are grateful to Laurene Kelly for the English revision of the paper. \\ Author details \\ ${ }^{1}$ Paediatrics Department, University of Pavia, Fondazione IRCCS Policlinico San Matteo, Piazzale Golgi 2, Pavia, Italy. ${ }^{2}$ Department of Endocrinological and Metabolic Sciences, University of Genova, Genova, Italy. ${ }^{3}$ Neonatal Intensive Care, IRCCS San Matteo, Pavia, Italy. ${ }^{4}$ Neonatal Intensive Care, Spedali Civili, Brescia, Italy.}

\section{Authors' contributions}

EB and AG participated in the design of the study, collection of data and helped to draft the manuscript. CM analysed and interpreted the data, performed the statistical analysis and drafted the manuscript. MA carried out the chromatographic analysis. PT performed the immunoassays. SP was involved in drafting and critically revising the manuscript. MB coordinated the study and helped to draft the manuscript. All the authors have read and approved the final manuscript.

\section{Competing interests}

The authors declare that they have no competing interests.

Received: 14 December 2009 Accepted: 18 March 2010

Published: 18 March 2010

\section{References}

1. Ong KKL, Ahmed ML, Emmett PM, Preece MA, Dunger DB: Association between postnatal catch-up growth and obesity in childhood: prospective cohort study. BMJ 2000, 320:967-971.

2. Forsen T, Eriksson J, Tuomilehto J, Reunanen A, Osmond C, Barker D: The fetal and childhood growth of persons who develop type 2 diabetes. Ann Intern Med 2000, 133:176-182.

3. Eriksson JG, Forsen T, Tuomilehto J, Jaddoe WW, Osmond C, Barker DJP: Effects of size at birth and childhood growth on the insulin resistance syndrome in elderly individuals. Diabetologia 2002, 45:342-348.

4. Yajnik CS, Fall CH, Vaidya U, Pandit AN, Bavdekar A, Bhat DS, Osmond C, Hales CN, Barker DJ: Fetal growth and glucose and insulin metabolism in four-year-old Indian children. Diabet Med 1995, 12:330-336.

5. Hofman PL, Cutfield WS, Robinson EM, Bergman RN, Menon RK, Sperling MA, Gluckman PD: Insulin resistance in short children with intrauterine growth retardation. J Clin Endocrinol Metab 1997, 82:402-406.

6. Phillips DI, Barker DJ, Hales CN, Hirst S, Osmond C: Thinness at birth and insulin resistance in adult life. Diabetologia 1994, 37:150-154.

7. Hales CN, Barker DJ, Clark PM, Cox LJ, Fall C, Osmond C, Winter PD: Fetal and infant growth and impaired glucose tolerance at age 64. BMJ 1991, 303:1019-1022.

8. Eriksson JG, Forsen TJ, Osmond C, Barker DJ: Pathways of infant and childhood growth that lead to type 2 diabetes. Diabetes Care 2003, 26:3006-3010.

9. Dunger DB, Ong KK: Babies born small for gestational age: insulin sensitivity and growth hormone treatment. Horm Res 2005, 64:58-65

10. McGarry JD: Disordered metabolism in diabetes: have we underemphasized the fat component? J Cell Biochem 1994, 55:29-38.

11. Boden G, Shulman Gl: Free fatty acids in obesity and type 2 diabetes: defining their role in the development of insulin resistance and $\beta$-cell dysfunction. Eur J Clin Invest 2002, 32:14-23.

12. Pittas $A G$, Joseph NA, Greenberg AS: Adipocytokines and insulin resistance. J Clin Endocrinol Metab 2004, 89:447-452.

13. Weyer C, Funahashi T, Tanaka S, Hotta K, Matsuzawa Y, Pratley RE, Tataranni PA: Hypoadiponectinemia in obesity and type 2 diabetes: close association with insulin resistance and hyperinsulinemia. J Clin Endocrinol Metab 2001, 86:1930-1935.

14. Waki H, Yamauchi T, Kamon J, Ito Y, Uccida S, Kita S, Hara K, Hada Y, Vasseur F, Froguel P, Rimura S, Nagai R, Kadowaki T: Impaired multimerization of human adiponectin mutants associated with diabetes. Molecular structure and multimer formation of adiponectin. J Biol Chem 2003, 278:40352-40363.

15. Pajvani UB, Hawkins M, Combs TP, Rajala MW, Doebber T, Berger JP, Wagner JA, Wu M, Knopps A, Xiang AH, Utzschneider KM, Kahn SE, Olefsky JM, Buchanan TA, Scherer PE: Complex distribution, not absolute amount of adiponectin, correlates with thiazolidinedione-mediated improvement in insulin sensitivity. J Biol Chem 2004, 279:12152-12162.

16. Blum WF, Englaro P, Hanitsch S, Juul A, Hertel NT, Muller J, Skakkebak NE, Heiman ML, Birkett M, Attanasio AM, Kiess W, Rascher W: Plasma leptin levels in healthy children and adolescents: dependence on body mass index, body fat mass, gender, pubertal stage, and testosterone. J Clin Endocrinol Metab 1997, 82:2904-2910.

17. Christou H, Connors JM, Ziotopoulou M, Hatzidakis V, Papathanassoglou E, Ringer SA, Mantzoros CS: Cord blood leptin and insulin-like growth factor levels are independent predictors of fetal growth. J Clin Endocrinol Metab 2001, 86:935-938.

18. Ong KKL, Ahmed ML, Emmett PM, Preece MA, Dunger DB: Cord blood leptin is associated with size at birth and predicts infancy weight gain in humans. J Clin Endocrinol Metab 1999, 84:1145-1148. 
19. Lee PA, Chernausek SD, Hokken-Koelega AC, Czernichow P: International Small for Gestational Age Advisory Board. International Small for Gestational Age Advisory Board consensus development conference statement: management of short children born small for gestational age, April 24-October 1, 2001. Pediatrics 2003, 111:1253-1261.

20. Kalberg J, Albertsson-Winkland K: Growth in full-term small-forgestational-age infants: from birth to final height. Ped Res 1995 38:733-739.

21. Cole TJ, Freeman JV, Preece MA: British 1990 growth reference centiles for weight, height, body mass index and head circumference fitted by maximum penalized likelihood. Stat Med 1998, 17:407-429.

22. Bozzola M, Schimpff RM: Neonatal serum growth-promoting activity measured in human lymphocytes: comparison of cord blood and capillary blood. Horm Metab Res 1985, 17:418-420.

23. Schimpff RM, Bozzola M, Zapf J: Serum thymidine activity and insulin-like growth factors in the neonatal period. Acta Endocrinol 1985, 110:140-144.

24. Ferrannini E, Mari A: How to measure insulin sensitivity. J Hypertens 1998, 16:895-906.

25. Cianfarani S, Maiorana A, Geremia C, Scirè G, Spadoni GL, Germani D: Blood glucose concentrations are reduced in children born small for gestational age (SGA), and thyroid-stimulating hormone levels are increased in SGA with blunted post-natal catch-up growth. J Clin Endocrinol Metab 2003, 88:2699-2705.

26. Cutfield WS, Bergman RN, Menon RK, Sperling MA: The modified minimal model: application to measurement of insulin sensitivity in children. J Clin Endocrinol Metab 1990, 70:1644-1650.

27. De Fronzo RA, Tobin JD, Andres R: Glucose clamp technique: a method for quantifying insulin secretion and resistance. Am J Physiol 1979, 237: E214-E223.

28. Levy-Marchal C, Chernichow P: Small for gestational age and the metabolic syndrome: which mechanism is suggested by epidemiological and clinical studies? Horm Res 2006, 65:123-130.

29. Huang TTK, Johnson MS, Gower BA, Goran Ml: Effect of changes in fat distribution on the rates of change of insulin response in children. Obes Res 2002, 10:978-984

30. Gungor N, Saad R, Janosky J, Arslanian S: Validation of surrogate estimates of insulin sensitivity and insulin secretion in children and adolescents. J Ped 2004, 144:47-55.

31. Woods K, Van Helvoirt M, Ong KKL, Mohn A, Levy J, De Zegher F, Dunger DB: The somatotropic axis in short children born small for gestational age: relation to insulin resistance. Ped Res 2002, 51:76-80.

32. Cutfield WS, Hofman PL: Simple fasting methods to assess insulin sensitivity in children. Horm Res 2005, 64:25-31.

33. Gohlke BC, Bartmann P, Fimmers R, Huber A, Hecher K, Roth CL: Fetal adiponectin and resistin in correlation with birth weight difference in monozygotic twins with discordant growth. Horm Res 2008, 69:37-44.

34. Kotani Y, Yokota I, Kitamura S, Matsuda J, Naito E, Kuroda Y: Plasma adiponectin levels in newborns are higher than those in adults and positively correlated with birth weight. Clin Endocrinol 2004, 61:418-423.

35. Lindsay RS, Walker JD, Havel PJ, Hamilton BA, Calder AA, Johnstone FD: Adiponectin is present in cord blood but is unrelated to birth weight. Diabetes Care 2003, 26:2244-2249.

36. Kamoda T, Saitoh H, Saito M, Sugiura M, Matsui A: Serum adiponectin concentrations in newborn infants in early postnatal life. Pediatr Res 2004, 56:690-693.

37. Soriguer Escofet FJ, Esteva de Antonio I, Tinahones FJ, Pareva A: Adipose tissue fatty acids and size and number of fat cells from birth to 9 years of age- a cross sectional study in 96 boys. Metabolism 1996, 45:1395-1401.

38. Mohlig $M$, Wegewitz U, Osterhoff $M$, Isken F, Ristow M, Pfeiffer AF, Spranger J: Insulin decreases human adiponectin plasma levels. Horm Metab Res 2002, 34:655-658.

39. Stefan N, Bunt JC, Salbe AD, Funahashi T, Matsuzawa Y, Tataranni PA: Plasma adiponectin concentrations in children: relationship with obesity and insulinemia. J Clin Endocrinol Metab 2002, 87:4652-4656.

40. Weiss R, Taksali SE, Caprio S: Development of type 2 diabetes in children and adolescents. Curr Diab Rep 2006, 6:182-187.

41. Ibáñez L, Lopez-Bermejo A, Diaz M, Angulo M, Sebastiani G, de Zegher F: High-molecular-weight adiponectin in children born small- or appropriate-for-gestational-age. J Pediatr 2009, 155:740-742.

42. Ibáñez L, López-Bermejo A, Díaz M, Marcos MV, Casano P, de Zegher F: Abdominal fat partitioning and high-molecular-weight adiponectin in short children born small for gestational age. J Clin Endocrinol Metab 2009, 94:1049-1052.

43. Martinez-Cordero C, Amador-Licona N, Guizar-Mendoza JM, HernandezMendez J, Ruelas-Orozco G: Body fat at birth and cord blood levels of insulin, adiponectin, leptin, and insulin-like growth factor-I in small for gestational age infants. Arch Med Res 2006, 37:490-494.

44. Soto N, Bazaes RA, Pena V, Salazar T, Avila A, Iniguez G, Ong KK, Dunger DB, Mericq MV: Insulin sensitivity and secretion are related to catch-up growth in small for gestational age infants at age 1 year: results from a prospective cohort. J Clin Endocrinol Metab 2003, 88:3645-3650.

45. Mericq V, Ong KK, Bazaes R, Pena V, Avila A, Salazar T, Soto N, Iniguez G, Dunger DB: Longitudinal changes in insulin sensitivity and secretion from birth to age three years in small- and appropriate-for-gestationalage children. Diabetologia 2005, 48:2609-2614.

46. Bazaes RA, Salazar TE, Pittaluga E, Pena V, Alegria A, Iniguez G, Ong KK, Dunger DB, Mericq MV: Glucose and lipid metabolism in small for gestational age infants at 48 hours of age. Pediatrics 2003, 111:804-809.

47. Monteiro POA, Victora CG: Rapid growth in infancy and childhood and obesity in the later life-a systematic review. Obes Rev 2005, 6:143-154.

doi:10.1186/1824-7288-36-26

Cite this article as: Bozzola et al.: Role of adiponectin and leptin on body development in infants during the first year of life. Italian Journal of Pediatrics 2010 36:26.

\section{Submit your next manuscript to BioMed Central and take full advantage of:}

- Convenient online submission

- Thorough peer review

- No space constraints or color figure charges

- Immediate publication on acceptance

- Inclusion in PubMed, CAS, Scopus and Google Scholar

- Research which is freely available for redistribution

Submit your manuscript at www.biomedcentral com/submit
C) Biomed Central 